\title{
趋向水环境保护的城市小流域土地利用生态化 生态实践路径、空间规划策略与开发断面模式
}

\section{Ecological Land Use Planning Towards Water Environment Protection at Urban Watershed: Ecological Practice Approaches, Spatial Planning Strategies and Development Transect Models}

颜文涛 邹锦

Yan Wentao, Zou Jin

\begin{abstract}
摘要: 解析城市小流域土地利用与河流水环境的相互关系, 可以帮助我们深刻理解土地利用规划与水环境管理的内在关联, 为趋向水环境保护的 城市土地利用生态规划提供科学依据。通过梳理前人实证性研究的相关结论, 本文总结凝练小流域土地利用和水环境相互关系的规律性认知; 探 讨水环境管理目标对土地利用的约束和引导; 提出整合水环境管理目标的城市小流域生态实践路径; 从城市小流域的土地利用规模控制、类型引 导和形态布局三个方面, 提出提升水环境绩效的空间规划策略; 针对强约束、中等约束、弱约束等三种不同约束类型的城市小流域, 采用断面梯 度分析法, 提出从河源到河口纵向梯度的三种典型的城市小流域开发断面概念模式。探索将量化水环境目标转译为空间规划策略, 可为改善城市 河流水环境质量提供空间框架，有助于采用规划手段有效地应对城市水环境问题。

Abstract: By analyzing the correlation between land use and water environment at the urban watershed, we can deeply understand the inter-relationships of land use planning and control to water environment management, and provide scientific basis of ecological land use planning for water environment protection. This paper summarizes the previous empirical results on the relationship between land use and water environment, discusses the restriction and guidance of water environment objectives on land use. Based on those results, this paper proposes the ecological practice approaches for urban watershed, which integrate water environment objectives to ecological land use planning. Furthermore, it puts forward spatial planning strategies for improving water environment performance, from three aspects, (non-)construction land use proportion, land use type and layout at the urban watershed. Lastly, from stream source to outlet, it proposes three conceptual models of ecological transect, aiming at three kinds of urban watershed with different degree of restriction. Exploring to translate quantitative water environment objectives into spatial planning strategies, can provide a spatial framework for improving water quality of urban streams, and also, help us to use land use planning tools to effectively cope with urban water environmental problems.
\end{abstract}

关键词: 城市小流域; 水环境绩效; 生态实践路径; 空间规划策略; 开发断面模式

Keywords: Urban Watershed; Water Environment Performance; Ecological Practice Approaches; Spatial Planning Strategies; Development Transect Models

国家重点研发计划课题资助项目（2017YFC0505705），国家自然科学基金面上项目（51278504），国家自然科学基金面上项目（51678087），中央 高校基本科研业务费专项资金资助项目（22120180267）

作者: 颜文涛 (通信作者), 博士, 同济大学建筑与城市规划学院, 高密度人居环境生态与节能教育部重点实验室, 教授, 博士生导师; 同济大学建筑 与城市规划学院生态智慧与生态实践研究中心副主任。yanwt@tongji.edu.cn 邹锦, 博士, 中国建筑科技集团上海中森建筑与工程设计顾问有限公司, 副总监 
快速城市化改变了小流域 ${ }^{11}$ 的地理形态和土地的自然 属性, 同时城市建设引起不透水表面和高密度人工排水系 统不断增加, 继而产生了显著的水环境效应 ${ }^{[1-4]}$ 。城市土地 利用与河流水环境存在着紧密的相互作用关系：城市开发 建设活动可以通过影响小流域的水质和水量, 进而对更高 一级的过境河流水环境产生重大影响; 而城市小流域的河 流水环境质量又会对水域周边及小流域土地利用产生潜在 的影响。由于缺乏面向水环境绩效 (2) 管理的空间规划方法 和策略, 实现健康的城市河流水环境目标依然面临巨大的 挑战 ${ }^{[5-6]}$ 。

解析城市小流域土地利用与水环境的相互关系, 可 以帮助我们深刻理解土地利用规划与水环境管理的内在关 联, 为趋向水环境保护的城市土地利用生态化提供科学依 据。国内外学者的研究主要聚焦于四个方面：(1) 流域和 河岸缓冲带尺度上土地利用和覆盖类型与河流水质指标 之间的相关关系; (2) 流域尺度上景观格局与河流水质 和水生生态系统的相关关系 ${ }^{19-11]}$; (3) 城市不透水表面对 洪水频率、径流总量和径流污染等水环境效应研究 ${ }^{[12-16]}$;

（4）基于水环境保护的流域景观格局优化和土地利用分区 管制研究 ${ }^{[17-18]}$ 。

探讨城市小流域水环境的土地利用增效机制，有利于采 用适宜的生态规划策略提升城市水环境绩效, 实际上是针对 小流域水环境管理的生态实践。那么, 为了提升城市水环境 绩效, 城乡生态规划过程应该控制哪些关键规划变量? 以及, 开发建设应该控制在小流域上游还是下游或中游? 笔者通过 梳理前人实证性研究的相关结论, 总结凝练小流域土地利用 和水环境相互关系的规律性认知, 探讨水环境管理目标对土 地利用的约束和引导, 尝试将量化水环境目标转译为空间规 划策略, 探索基于反馈调节的城市小流域生态实践路径, 形 成水环境导向下的城市小流域生态断面分区模式, 为城市小 流域水环境管理提供综合框架。

\section{1 小流域土地利用对河流水环境的影响规律认知}

大都市区快速城市化过程中，森林、水域、湿地等非建 设用地转化成居住、工业或商业等建设用地, 导致不透水表面 的大量增加和水系自然形态的改变, 影响小流域的自然水文过 程和营养物质的产生、传输和累计过程, 从而产生显著的水 环境效应 ${ }^{[45]}$ 。建设用地与不透水表面存在显著的线性正相关 关系, 通过计算不同类型建设用地的不透水表面系数 ${ }^{3}$, 可 以将建设用地面积转化为不透水表面面积 ${ }^{(4)}$ 。因此, 建设用 地和不透水表面均可作为影响水环境的规划控制变量。通过 探讨土地利用规模、类型和形态等对河流水环境的影响规律, 可为采用土地利用控制手段管理小流域水环境提供科学依据。

\section{1 小流域土地利用规模对河流水环境的影响效应}

小流域土地利用规模是指建设用地（或非建设用地）数 量及比例关系, 不同的建设用地（或非建设用地）数量或比例 关系对河流水环境存在不同的影响效应。小流域建设用地增加 直接导致不透水表面的增大, 将改变地表径流特性, 进而影响 城市小流域的河流径流总量和洪峰流量, 短时间内增大降雨径 流峰值, 长时间内增加洪水频率和径流总量。不透水表面增 大加剧了小流域中小洪水的峰值和频率, 但对规模大、重现 期长的洪水（如百年一遇以上的洪峰）影响不大 ${ }^{[14]}$ 。或者说, 不透水表面增大对河流径流总量和洪峰流量的影响, 小雨雨情 受不透水表面扩展的影响显著大于暴雨雨情。另外, 不透水表 面和雨水沟渠系统这两个因素同时增加了径流累积速率, 减 少了峰值水位滞后时间 (lag time), 导致径流峰值增大 ${ }^{[15]}$ 。不 透水表面率在 20\% 80\% 之间, 小流域的径流总量将快速增长， $20 \%$ 不透水表面率可能是径流迅速增加的阈值（表 1)。

小流域建设用地（或不透水表面）的数量和比例增大, 产生的点源和径流污染负荷排放将影响河流水质。大量的不透 水表面使城市径流温度升高, 以及河岸植被破坏, 将导致河流

(1) 城市小流域是指以分水岭和城市河道出口断面为界, 以城市溪流为地貌特征的一个集水区域, 集水面积在 $10 \sim 100 \mathrm{~km}^{2}$ 左右。城市建设区与小 流域空间单元密切相关——城市建设区可以位于小流域单元中, 或由若千个小流域单元构成城市建设区。转引自: 龚清宇, 王林超, 唐远平. 中 小流域尺度内雨水湿地规模模拟与设计引导, 建筑学报, 2009(2): 48 .

(2) 城市河流水环境绩效是指实现水环境目标的程度, 即河流水环境绩效 = 河流水环境质量的实现指标/河流水环境的规划指标。绩效大于 1 表示 规划实施后水环境质量达到并超过规划目标，绩效小于 1 表示规划实施后水环境质量没有达到规划目标。衡量水环境绩效的水质指标包括化 学需氧量 $(\mathrm{COD})$ 、生化需氧量 (BOD)、总磷 (TP) 、总氮 ( TN) 、悬浮物 ( TSS) 等, 以及地表径流总量、径流峰值、径流时间、径流系数、 地下水储存量等水量指标, 以及水系结构、河网形态等指标, 这些指标可以表征城市河流水环境的健康程度。

(3) 各类建设用地的不透水表面系数, 美国高密度居住区 (high density residential area, 3 7 住宅单位/英亩) 不透水表面系数为 $0.20 \sim 0.40$, 多户 家庭居住区 (multifamily area，7 30 住宅单位/英亩) 不透水表面系数为 $0.35 \sim 0.60$, 普通商业用地不透水表面系数为 0.85 , 工业用地不透水表 面系数为 0.75 , 购物中心不透水表面系数为 0.95 。转引自 Soil Conservation Service, 1975 。

(4) 由于城市规划管理技术规定存在差异, 不同类型建设用地的不透水表面系数不同（颜文涛\&何强，2016）。需要依据采样统计结果，计算不同 类型建设用地的不透水表面系数。采用算式 (式中为第 $\mathrm{i}$ 类建设用地面积, 为第 $\mathrm{i}$ 类建设用地不透水表面率, 为第 $\mathrm{i}$ 类建设用地不透水表面的面积, 为建设用地不透水表面的总面积), 可以将建设用地面积转化为不透水表面面积。 
水体日平均温度的上升, 进而影响水体水环境和水生生态系统 的健康。小流域建设用地与河流水质主要指标之间存在显著的 相关关系 ${ }^{[7,24]}$ 。不透水表面增大将减少地下水补给量, 导致地 下水位降低以及非雨期城市河流基流更小, 以及水生生态系统 退化。不透水表面率达到 30\% 时, 排人水体的 TP 和 TSS 增加, 将导致水域的富营养化 ${ }^{[20]}$ 。在滨海地区，地下水位下降还可 能导致地面下陷以及海水人侵等负向水环境效应。不透水表面 率可以用来推测河流当前和未来的水质, 其增加直接影响河 流生态系统的健康状态 : 当小流域不透水表面率在 $10 \%$ 以内, 能有效维持河流水环境的健康状态; 当小流域不透水表面率 在 10\% 30\%, 河流水环境的健康状态将受到影响 ; 当小流域 不透水表面率超过 $30 \%$, 河流水环境的健康状态将会退化 ${ }^{[12]}$ 。 国内相关研究表明，当城市建设用地比例达到 $20 \%$, 该小流 域的河流水环境退化严重（表 1)。与发达国家进行比较后发 现, 国内城市建设对水环境影响的阈值更小, 说明城市建设过 程中可能存在局部点源污染的直接排放情况。

\section{2 小流域土地利用类型对河流水环境的影响效应}

不同土地利用类型具有不同的水环境影响效应。建设用 地对水环境存在负向效应, 非建设用地（除传统农业用地）
对水环境存在正向效应。有机废物和营养物主要来源于居住 用地 $(R)$ 、公共管理和公共服务用地 (A)、商业服务业设 施用地 (B)、城市道路用地 (S1)、农业用地 (E2) 等用地 类型。河流沉积物主要来源于建设用地施工场地以及农业和 采矿用地。热废水、有毒和人工高分子合成物废水、重金属 污染物和农药污染物主要来源于工业用地 (M) 、采矿用地 $(\mathrm{H} 5)$ 、农业用地 (E2)。居住用地比例与 TN 和 TP 存在显 著的正相关关系, 公共设施用地比例与 $\mathrm{TN}$ 和 $\mathrm{BOD}$ 存在显 著的正相关关系, 道路交通用地与 TN 有正相关关系, 林地 比例与各类水质指标存在负相关关系 ${ }^{[3]}$ 。理解各类土地用途 的污染物输出特征 (表 2), 有利于规划决策者确定改变水 环境潜在问题的关键区域。

各类用地年均污染负荷输出系数不同。其中, 城市道路 用地（S1）和广场用地（G3）的单位用地年均径流污染负 荷输出较大, 其他建设用地如居住用地 (R)、公共管理和公 共服务用地（A)、商业服务业设施用地（B)、工业用地（M) 等的单位用地年均径流污染负荷输出中等, 草地 (E2) 和 林地 (E2) 的单位用地年均径流污染负荷输出最小 (表 3)。 由于各个小流域的土壤条件、水文地质条件、地理形态、植 被条件、河流形态结构等存在差异，不同区域的城市用地的

表 1 城市小流域土地利用规模对河流水环境绩效的影响研究归纳

\begin{tabular}{|c|c|c|c|}
\hline 作者 & 研究尺度 & $\begin{array}{l}\text { 不透水表面率 / \% } \\
\text { （建设用地比例） }\end{array}$ & 水环境绩效说明 \\
\hline \multirow{3}{*}{ 利奥波德（Leopold） ${ }^{\mid 15]}$} & \multirow{3}{*}{$2.6 \mathrm{~km}^{2}$} & 20 & 年均洪峰流量可增大到开发前的 1.5 倍 \\
\hline & & 40 & 年均洪峰流量可增大到开发前的 2.3 倍 \\
\hline & & 80 & 年均洪峰流量可增大到开发前的 4.2 倍 \\
\hline \multirow{2}{*}{ 克莱因 (Klein) ${ }^{[19]}$} & \multirow{2}{*}{$2.4 \sim 7.3 \mathrm{~km}^{2}$} & 12 & 可以维持健康的河流生态系统 \\
\hline & & 30 & 河流生态系统退化严重 \\
\hline 托德等 (Todd et al.) ${ }^{[20]}$ & $234 \mathrm{~km}^{2}$ & 30 & 水体 TP 和 TSS 污染负荷的增加将导致水域富营养化 \\
\hline \multirow{2}{*}{ 布思（Booth） ${ }^{[21]}$} & \multirow{2}{*}{$13 \mathrm{~km}^{2}$} & $10 \sim 15$ & 鱼类和水生昆虫多样性迅速下降 \\
\hline & & 30 & 河流水生生态系统退化严重 \\
\hline \multirow{2}{*}{ 阿诺德和吉本斯（Arnold \& Gibbons） ${ }^{[12]}$} & \multirow{2}{*}{ 多尺度 } & 10 & 河流水环境质量开始退化 \\
\hline & & 30 & 河流水环境质量退化不可逆转 \\
\hline 布兰和班德（Brun \& Band） ${ }^{\mid 13]}$ & $91 \mathrm{~km}^{2}$ & $20 \sim 80$ & 小流域径流总量将快速增长, 其中 $20 \%$ 可能是径流总量迅速增加的阈值 \\
\hline 巴杜里等（Bhaduri et al.） ${ }^{[22]}$ & $70.5 \mathrm{~km}^{2}$ & 增加了 18 & 年均径流体积增长了 $80 \%$ 左右 \\
\hline \multirow{2}{*}{$\mathrm{CWP}^{[23]}$} & \multirow{2}{*}{ 子流域尺度 } & $10 \sim 25$ & 河流健康度开始快速下降 \\
\hline & & 25 & 难以维持良好的健康状态 \\
\hline 刘珍环 ${ }^{[16]}$ & 深圳市 11 个小流域 & 增加了 73.21 & 枯水年年径流总量增长了 $56.34 \%$, 丰水年年径流总量增长了 $44.71 \%$ \\
\hline \multirow{2}{*}{ 颜文涛和何强 ${ }^{1}$} & \multirow{2}{*}{$10 \sim 100 \mathrm{~km}^{2}$} & (20 以下) & $\begin{array}{l}\mathrm{NH} 3-\mathrm{N} \text { 的年平均水质达到 III 类标准的河流占 } 75 \% \text { 左右; } \mathrm{TP} \text { 年平均水质达 } \\
\text { 到 } \mathrm{V} \text { 类标准的河流占 } 50 \% \text { 左右 }\end{array}$ \\
\hline & & (20 以上) & $\begin{array}{l}\mathrm{NH} 3-\mathrm{N} \text { 的年平均水质达到 } \mathrm{V} \text { 类标准的河流占 } 25 \% \text { 左右; } \mathrm{TP} \text { 年平均水质均 } \\
\text { 为劣 } \mathrm{V} \text { 类标准 }\end{array}$ \\
\hline
\end{tabular}

(1) 该部分结论引用自“十二五”国家科技重大专项课题“重庆两江新区城市水系统构建技术研究与示范”研究报告 (2016), 课题负责人: 颜文涛、何强。 
非点源污染负荷输出系数有一定差异。城市点源污染负荷 主要来源于居住用地 ( $R$ )、公共管理和公共服务用地 (A)、 商业服务业设施用地 (B)、工业用地 (M) 等建设用地, 城 市产业结构和生活方式决定了点源年均污染负荷输出系数。 通过采用各类用地的年均污染负荷输出参数, 初步估算土地 利用方案的污染负荷输出总量, 可以帮助规划师确定规划发 展后的潜在水环境影响区域, 为调整优化规划方案并确定空 间环境管制提供基本依据。

\section{3 小流域土地利用形态对河流水环境的影响效应}

假如土地利用规模和类型相同, 而土地利用类型的空间 组合方式不同, 也将产生不同的水环境效应。小流域的用地 多样性、斑块密度、边界密度, 以及集聚度、斑块尺寸、连 通度等, 是影响水环境质量的土地利用形态指数 ${ }^{[7]}$ 。小流域 各类用地越分散 (斑块密度和边界密度大, 景观破碎化程度 大) 的情况下, 河流水体有机污染和营养物质浓度可能越 高。建设用地和非建设用地布局形态都将不同程度地影响河 流水环境, 主要表现为两方面。(1) 小流域内城市建设用 地的破碎化, 可能导致更高的水环境污染, $\mathrm{COD} 、 \mathrm{BOD}$ 水
质指标对建设用地破碎化程度较敏感。建设用地与水域邻接 边界密度越大, 可能导致 TP 浓度越高, 可能是由于各类不 透水表面与河流水域邻接面增加, 主要以颗粒态形式存在的 $\mathrm{TP}$ 可以快速进人水体, 无法在水域外沉积下来。但是, TN 对城市建设用地形态结构基本不敏感, 可能是其主要以溶解 态形式存在, 难以通过地表自然物理过程得到降解。增加建 设用地与水体的绿色缓冲空间, 有利于维持更好的水环境质 量。(2) 非建设用地的破碎化和形态简单化, 将导致更高的 COD、BOD 和 TP 浓度。相对而言, 适宜的大集中小分散 的土地利用形态模式, 水环境质量可能会更好。因此, 具有 相对聚集和形态复杂的非建设用地, 有利于维持更好的小流 域水环境质量。总体而言, 城市小流域内建设用地和非建设 用地的适度紧凑集中的布局形态, 具有良好的环境学意义。

同样的建设用地规模和类型, 若建设活动发生在上游支 流区、小流域的陡坡区、库塘蓄水区、地下水补给区等环境敏 感区, 将对河流水环境产生更大的影响; 若建设活动发生在滨 水区缓冲带, 将导致水质恶化和水生生物栖息地减少。小流域 上游支流的自然林地为河流的水源涵养地, 在这些区域开发 建设, 将对整条河流产生严重影响, 会降低河流基流并影响

\section{表 2 各类土地用途的污染物输出特征}

\begin{tabular}{|c|c|c|c|c|c|c|c|}
\hline 土地用途 & 污水类型 & $\begin{array}{c}\text { 有机废物 } \\
(\text { COD、BOD) }\end{array}$ & $\begin{array}{l}\text { 营养物 (TN、 } \\
\text { TP、NH3-N) }\end{array}$ & 沉积物 & 热废物 & $\begin{array}{l}\text { 有毒废物和人工 } \\
\text { 合成化合物 }\end{array}$ & $\begin{array}{l}\text { 其他 (细菌、石油、 } \\
\text { 重金属、漂浮物等) }\end{array}$ \\
\hline $\begin{array}{l}\text { 居住用地 (R)、公共管理和公共服务用 } \\
\text { 地 (A)、商业服务业设施用地 (B) }\end{array}$ & 生活污水 & ? & ? & - & - & - & - \\
\hline 工业用地 (M) & 工业废水 & (0) & () & - & (0) & (0) & (0) \\
\hline 城市道路用地 (S1)、广场用地 (G3) & 城市雨水径流 & $\bullet$ & (O) & (0) & - & - & (0) \\
\hline 各类施工场地 & 建设径流 & (0) & - & ○ & - & - & - \\
\hline 农业用地（E2） & 农业排水 & 0 & 0 & (0) & - & () & - \\
\hline 采矿用地 (H5) & 矿山排水 & - & - & (0) & - & (0) & - \\
\hline
\end{tabular}

注：表示基本影响因子, ○表示可能条件下的重要影响因子, 一表示该项未发现。

\section{表 3 各类用地的污染负荷输出系数}

\begin{tabular}{|c|c|c|c|c|c|c|}
\hline \multirow{2}{*}{ 用地类型 } & \multicolumn{3}{|c|}{ 点源年均污染负荷输出系数 $\left(\mathrm{t} \cdot \mathrm{km}^{-2} \cdot \mathrm{a}^{-1}\right)$} & \multicolumn{3}{|c|}{ 非点源年均污染负荷输出系数 $\left(\mathrm{t} \cdot \mathrm{km}^{-2} \cdot \mathrm{a}^{-1}\right)$} \\
\hline & BOD & TN & TP & BOD & TN & $\mathbf{T P}$ \\
\hline 居住用地（R） & $180.0 \sim 465.4$ & $35.8 \sim 93.1$ & $6.0 \sim 15.5$ & 39.23 & 3.40 & 0.26 \\
\hline 公共管理和公共服务用地 (A) & $107.4 \sim 250.6$ & $21.5 \sim 50.1$ & $3.6 \sim 6.0$ & 40.54 & 3.52 & 0.28 \\
\hline 商业服务业设施用地（B） & $180.0 \sim 716.0$ & $35.8 \sim 143.2$ & $6.0 \sim 23.9$ & 54.13 & 5.02 & 0.32 \\
\hline 工业用地（M） & - & - & - & 45.48 & 3.81 & 0.31 \\
\hline 城市道路用地 (S1) & - & - & - & 107.47 & 6.06 & 0.88 \\
\hline 广场用地 (G3) & - & - & - & 64.07 & 7.08 & 0.45 \\
\hline 人工绿地 (G) & - & - & - & - & $1.00^{*}$ & $0.02^{*}$ \\
\hline 耕地 (E2) & - & - & - & - & $2.90^{*}$ & $0.09^{*}$ \\
\hline
\end{tabular}

注: 表中各类用地点源污染负荷系数根据《排水工程规划规范》(GB50282) 和《室外排水设计规范 (2014 年修订版)》(GB50014) 建议的污水量 和污水水质计算得到。表中各类用地非点源污染负荷输出系数是重庆都市区相关研究结论, 引自“十二五”国家科技重大专项课题“重庆两 江新区城市水系统构建技术研究与示范”研究报告的有关成果, 课题负责人: 颜文涛、何强。“数据引自参考文献 [25]。 
水生生态系统健康, 而水环境治理成本将远远超过可得到的 经济利益。陡坡区的开发将破坏稳定的植被覆盖, 建设施工 过程以及建成后地表径流增大将加大下游的侵蚀作用, 城市 小流域水体的大多数悬浮物主要来源于这些高侵蚀区的开发 活动。若在蓄水区上游进行土地开发, 将在河流开阔地或库 塘蓄水区产生沉积, 从而影响水体的正常功能, 并可能导致 溪流逐渐退化消失。库塘湿地区、地形凹陷的高渗透土壤区 和暴露于地表的地下蓄水层区, 构成地下水补给区, 若在这 些区域布置各类建设用地, 可能减少地下蓄水层的补给水量 并导致污染物进人地下蓄水层, 引起大面积的地下水位下降, 产生河流基流减少和地面沉降等综合的负向水环境效应。

\section{2 城市河流水环境对小流域土地利用的控制与引导}

水环境质量具有内在的经济、社会、生态和美学价值, 将影响小流域土地利用模式。然而, 通常情况下城市土地利 用规划更重视社会和经济因素, 较少关注水环境管理与土地 利用的内在关联，容易忽视小流域水环境质量对土地利用的 约束和引导。优良的水环境质量包含良好的水质、稳定的水 量、健康的水生生态系统及其具有的水域愉悦感。其中，良 好的水质和稳定的水量是保障水域其他功能的基础, 是饮用 水源、渔业用水、景观用水、工业用水、农业灌溉用水、水 运航行等水域环境功能的基础, 也是体现城市特色和环境品 质的特质要素。河流水质恶化或黑臭将影响环境净化、水源 供应、文化娱乐、生物保护等所有水环境功能的有效发挥, 并以多种方式影响邻近水域的土地利用类型和价值。由于退 化水环境的修复成本巨大, 因此水环境现状条件是确定水环 境主导功能的重要依据。

\section{1 城市河流水环境对小流域建设用地的影响约束}

城市河流水量、水质及视觉特征会影响人们临水的行为 活动，对城市产业布局和社区生活方式产生潜在的影响。良 好的河流水环境可以吸引居住、商业和娱乐等人类滨水活
动, 并提升邻近水域的土地经济价值。相反, 退化的河流水 环境由于存在不良的视觉和嗅觉感知, 会排斥上述的各项 活动, 并降低滨水区的土地经济价值。不同的水环境质量对 城市建设用地的影响和约束, 主要表现在三个方面（表 4)。 （1）水量充足稳定并达到 II 类水质的水环境条件, 适合自 然保护区或饮用水源保护区等水环境功能。这类小流域具有 最强的土地利用约束, 天然水质保持是所有活动的基础, 禁 止水体娱乐的开发活动, 在建设用地总量控制的基础上可以 布置小规模紧凑布局的居住用地 (R)。(2) 达到 III类水质的 水环境条件, 适合饮用水源或景观娱乐等水环境功能。这类 小流域具有较强的土地利用约束, 可以布置适度规模的居住 用地 $(\mathrm{R})$ 、公共管理和公共服务用地 (A) 和商业服务业设 施用地 (B)，但要注意对降雨径流污染负荷的控制。该类小 流域不适宜布置二、三类工业用地。（3）水量充足稳定和达 到 IV 类或 $\mathrm{V}$ 类水质的水环境条件, 适合景观娱乐或工业用水 等水环境功能。这类小流域的土地利用约束强度中等偏弱, 可以布置规模较大的各类建设用地 (R、A、B、S、M)。另外, 污水处理厂周边和下游受影响区域、截流干管溢流口附近宜 布置工业、物流等建设用地。

\section{2 城市河流水环境对小流域非建设用地的功能引导}

良好的水质和稳定的水量是健康的河流水生生态系统的 前提和基础。水域、林草地、湿地等城市非建设用地可以提 供水源涵养、水质净化、洪涝调节、侵蚀控制等生态系统服 务功能 ${ }^{[2627]}$ 。河流水环境主导功能对非建设用地生态系统服 务的引导作用, 表现在四个方面（表 5)。（1）以自然保护和 饮用水源为水环境主导功能的城市河流, 具有内在适宜的综 合价值 (如饮用水源供给、游悡美学和生物多样性保护等), 对非建设用地布局的引导作用最强。应该引导该类小流域维 持完整的生态系统结构, 维护或修复良好的自然覆被; 可以 布置具有一定游喤功能的公园绿地, 严格限制产生非点源污 染的农业用地。(2) 以景观娱乐为主导功能的城市河流, 对

表 4 城市河流水环境功能对小流域建设用地的类型约束

\begin{tabular}{|c|c|c|c|c|c|c|c|c|}
\hline \multirow{2}{*}{ 水环境现状条件 } & \multirow{2}{*}{$\begin{array}{l}\text { 水环境规划 } \\
\text { 主导功能 }\end{array}$} & \multirow{2}{*}{$\begin{array}{c}\text { 建设用地 } \\
\text { 类型约束 } \\
\text { 强度 }\end{array}$} & \multicolumn{6}{|c|}{ 城市小流域建设用地的类型约束 } \\
\hline & & & $\begin{array}{c}\text { 工业用地 } \\
(\mathbf{M})\end{array}$ & $\begin{array}{c}\text { 居住用地 } \\
\text { (R) }\end{array}$ & $\begin{array}{l}\text { 公共管理和公共 } \\
\text { 服务用地 (A) }\end{array}$ & $\begin{array}{l}\text { 商业服务业设 } \\
\text { 施用地（B） }\end{array}$ & $\begin{array}{l}\text { 公园绿地 } \\
(\mathbf{G})\end{array}$ & $\begin{array}{c}\text { 城市道路交通设施 } \\
\text { 用地 }(\mathbf{S} 1)\end{array}$ \\
\hline 水量充足稳定, 达到 II 类水质 & 自然保护；饮用水源 & 强 & $\times$ & $\mathrm{O}$ & O & $x$ & - & O \\
\hline 水量充足稳定, 达到 III类水质 & 饮用水源；景观娱乐 & 中 & $\times$ & ○ & O & O & ○ & O \\
\hline 水量不足, 达到 III类水质 & 景观娱乐 & 中 & $x$ & 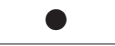 & 0 & 0 & - & $\mathrm{O}$ \\
\hline 水量充足稳定, 达到 IV 类水质 & 景观娱乐; 工业用水 & 弱 & - & - & ○ & - & - & - \\
\hline 水量充足稳定, 达到 $\mathrm{V}$ 类水质 & 农业用水 & 弱 & $\mathrm{O}$ & - & ○ & $\bullet$ & $\bullet$ & $\bullet$ \\
\hline 水量不稳定，易发洪涝 & 泄洪功能 & 弱 & O & O & $\mathrm{O}$ & O & O & O \\
\hline
\end{tabular}

为适宜的土地利用类型, ○为限制 (条件许可时适宜) 的土地利用类型, $\times$ 为不适宜的土地利用类型。 
非建设用地布局的引导作用中等。需要适度限制上游水源涵 养区的开发活动, 强调最大程度降低对自然过程的干预, 生 态空间结构需要考虑能够支撑自然水文过程。(3) 以工业用 地和农业用水为主导功能的城市河流, 对非建设用地布局的 引导作用较弱。该类小流域需要维持水体的净化功能和保持 水域的水环境容量, 基于修复关键的生态系统结构控制土壤 侵蚀。(4) 以泄洪排水为主导功能的城市河流, 重点提升非 建设用地的洪涝调节服务能力。该类河流所在的小流域应该 保存蓄滞洪区的自然特性, 通过自然调节过程减缓洪涝强度。 另外, 地下水补给区、河流廊道及库塘湿地等河流水质保持 区, 需要维持或修复该区域的环境净化功能, 适宜布置自然 林草地等用地类型。

\section{3 整合水环境目标的城市小流域生态实践路径与 空间策略}

城市土地利用将产生显著的水环境效应, 而水环境主 导功能及水质目标将影响小流域的社会经济增长方式。深刻 理解土地利用与水环境的内在关联性, 将水环境保护整合进 土地利用规划框架中, 形成城市小流域土地利用生态实践路 径, 提出适宜的生态规划策略, 降低城市化的负向水环境效 应, 可有效提升土地利用规划的水环境绩效。城市小流域水 文单元与城市空间单元的关系为：城市小流域 (watershed, $10 \sim 100 \mathrm{~km}^{2}$ 左右) 与总规层次的城市规划区相关; 次小流 域 (subwatershed, 1 10 $\mathrm{km}^{2}$ 左右) 与控规管理单元相关, 也是社区规划需要关注的环境单元; 集水区 (catchment, $0.1 \sim 1 \mathrm{~km}^{2}$ 左右）是城市排水分区管理单元, 与街区城市设 计层次相关; 子集水区 ( subcatchment, 0.01 0.1 $\mathrm{km}^{2}$ 左右) 与规划设计中的地块尺度相当（图 1)。

\section{1 整合水环境目标的小流域生态实践路径}

生态实践是指 “人类为自身生存和发展营造安全与和谐 的社会一生态环境 (即 “善境”) 的社会活动” ${ }^{[28]}$, 包含了
生态规划与实施、设计与营造、管理与反馈等方面内容。城 市小流域水环境管理实践, 是同时具有建设开发、保护维育、 社会文化、修复更新、污染治理等多种特征的生态实践类型。 笔者依据社会经济发展目标确定城市增长率, 将城市建设用 地总量分解至小流域空间单元, 形成小流域土地利用规划方 案, 采用单位用地或人均负荷指标 (如各类用地污染负荷输 出系数或人均污染负荷) 预测河流污染物浓度和总负荷, 制 定污水收集和处理方案, 构成基于 “增长需求 $\rightarrow$ 排水服务” 的生态实践路径一（图 2 左）。这类满足需求的 “需求 $\rightarrow$ 供 应”单向线性控制方法, 依赖于工程结构技术的污水末端处 理方式, 只是将土地利用作为需求参数, 无法提供水环境问 题的系统性解决路径 ${ }^{[6]}$, 没有主动响应水环境功能和水质目 标, 仅适用于水环境容量较大的低增长发展模式。

在实践路径一的基础上, 叠加上水环境影响评估后的 两路反馈调节环, 形成基于 “需求 $\rightarrow$ 供应 $\rightarrow$ 反馈” 的小流 域生态实践路径二（图 2 中）。该方法基于小流域生态特征, 确定小流域增长规模。当超过小流域水环境承载力, 无法 达到期望的水环境质量标准时, 通过第一个反馈环调整社 会水系统方案（涉及取水系统、用水系统、污水排水系统、 雨水排水系统等), 减少社会水系统对自然水环境的影响 ${ }^{[29]}$ 。 若第一个反馈环仍无法达到规划的水环境质量标准, 通过 第二个反馈环调节土地利用规划方案, 在小流域增长规模 不变的前提下, 识别水环境的潜在影响区域, 在小流域范

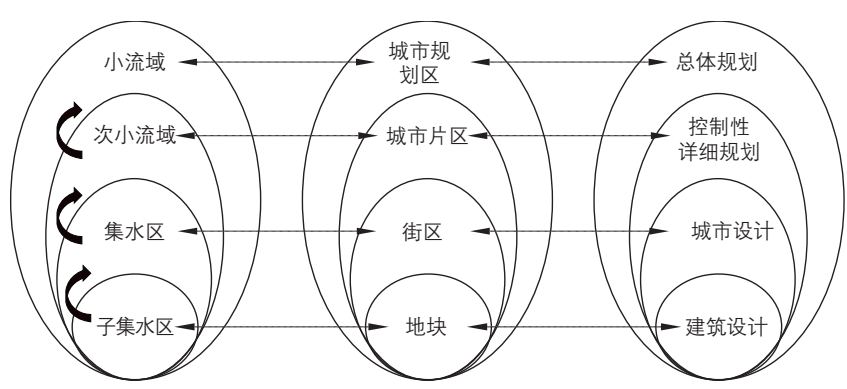

图 1 小流域水文单元与城市空间单元和规划层次的关系

表 5 城市河流水环境对小流域非建设用地的功能引导

\begin{tabular}{|c|c|c|c|c|c|c|c|c|c|}
\hline \multirow[b]{2}{*}{ 水环境现状条件 } & \multirow[b]{2}{*}{ 水环境规划主导功能 } & \multirow{2}{*}{$\begin{array}{c}\text { 对非建设用 } \\
\text { 地功能引导 } \\
\text { 强度 }\end{array}$} & \multicolumn{7}{|c|}{ 城市小流域非建设用地的功能引导 } \\
\hline & & & $\begin{array}{l}\text { 水源 } \\
\text { 涵养 }\end{array}$ & $\begin{array}{l}\text { 游秝 } \\
\text { 休闲 }\end{array}$ & $\begin{array}{c}\text { 生物多样性 } \\
\text { 保护 }\end{array}$ & $\begin{array}{c}\text { 蓄滞洪 } \\
\text { 调节 }\end{array}$ & $\begin{array}{c}\text { 水质保持和 } \\
\text { 净化 }\end{array}$ & $\begin{array}{l}\text { 侵蚛 } \\
\text { 控制 }\end{array}$ & $\begin{array}{l}\text { 农业 } \\
\text { 生产 }\end{array}$ \\
\hline 水量充足稳定, 达到 II 类水质 & 自然保护 ; 饮用水源 & 强 & $\sqrt{ }$ & - & $\checkmark$ & - & $\sqrt{ }$ & $\sqrt{ }$ & $\times$ \\
\hline 水量充足稳定, 达到 III类水质 & 饮用水源；景观娱乐 & 中 & $\sqrt{ }$ & $\sqrt{ }$ & - & - & $\sqrt{ }$ & $\sqrt{ }$ & $\times$ \\
\hline 水量不足, 达到 III类水质 & 景观娱乐 & 中 & - & $\checkmark$ & - & - & $\sqrt{ }$ & $\checkmark$ & - \\
\hline 水量充足稳定, 达到IV类水质 & 景观娱乐 ; 工业用水 & 弱 & - & $\checkmark$ & - & - & $\sqrt{ }$ & $\checkmark$ & - \\
\hline 水量充足稳定, 达到 $\mathrm{V}$ 类水质 & 农业用水 & 弱 & $\checkmark$ & - & - & - & $\sqrt{ }$ & $\checkmark$ & $\sqrt{ }$ \\
\hline 水量不稳定, 易发洪涝 & 泄洪功能 & 弱 & $\sqrt{ }$ & - & - & $\sqrt{ }$ & - & - & - \\
\hline
\end{tabular}

注: $\sqrt{ }$ 为规划引导的生态服务功能, $\times$ 为规划限制的生态服务功能, 一为通常情况下不涉及。 
围内重新分配增长空间, 调整土地利用规划方案, 综合平 衡影响水环境的各类用地安排和污染负荷的空间分布, 重 新调整社会水系统，如果不满足水环境条件将继续反馈并 重复这一过程。通过比较多个反馈调整方案的水环境绩效, 再结合成本经济效益准则，选择水环境目标可达、规划可 实施的土地利用方案。该路径适用于存在水环境容量限制 的高增长发展模式。

在小流域实践路径二的基础上，加人水环境质量标准和 水环境主导功能的约束, 另外加上水环境影响评估后的三路 反馈调节环, 形成基于 “增长需求 $\rightarrow$ 服务供应 $\rightarrow$ 反馈调节” 的小流域生态实践路径三（图 2 右）。从实践全过程回应水 环境目标的需求, 主动响应了水环境功能和水质目标, 从水 环境与土地利用的内在关联性, 将土地利用规划和控制作为 水环境的管理工具, 通过权衡选择后提出相应的措施。将水 环境质量标准、可接受的污染负荷分布以及水环境的地方感 和美学价值 ${ }^{[30-31]}$ 转换为小流域人口增长和土地开发容量, 制 定与社会经济发展目标一致的水环境质量标准和主导功能, 确定合理的土地利用模式。通过在路径二基础上加上的第三 路反馈调节环, 水环境标准可以影响小流域的增长规模, 甚 至进一步影响城市社会经济发展目标。该路径将量化的环境 管理目标引人土地利用规划, 从生态实践的整体视角提供水 环境管理的实施框架。

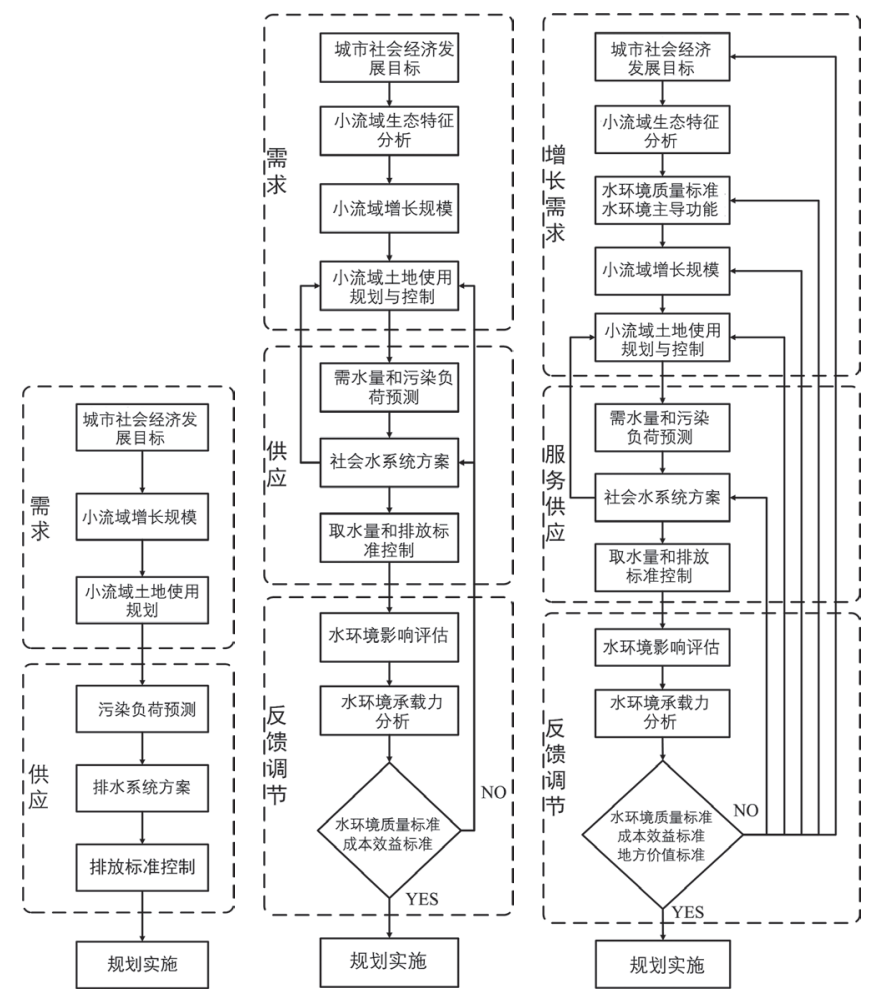

图 2 城市小流域生态实践路径一 (左)、路径二 (中)、路径三 (右)

\section{2 趋向水环境保护的城市小流域土地利用生态化策略}

基于用地布局结构的水环境效应, 探索水环境承载力及 对小流域开发模式的影响, 研究水环境容量约束和用地功能 安排的相互关系, 将城市水环境功能目标转化为小流域土地 开发的空间约束, 从小流域土地利用规模、类型和形态提出 控制和引导要求, 具体的生态化策略如下。

策略一：规模控制策略, 确定 “应该开发多少”。根据 城市规划区社会经济发展目标, 基于人口和经济增长率, 考 虑建设用地现状规模, 初步确定城市规划区增长规模。依据 规模效应、水环境敏感区和开放空间的开发限制、水环境功 能约束原理, 将城市增长规模分解到各个小流域空间单元上。 小流域建设用地承载量可根据公式计算: $C A=\min (\gamma \cdot B A$, $(B A-$ $E S A), U A)$ 。式中 $C A$ 为小流域建设用地总规模, $B A$ 为小流 域总面积, $E S A$ 为需要保留或保护的小流域水环境敏感区和 开放空间面积, $U A$ 为分解到小流域的城市建设用地总量（含 建设用地的存量和增量), $\gamma$ 为小流域土地利用强度系数 (取 值范围是 $0 \sim 1$, 小流域水环境质量标准越高, 小流域约束强 度越大, $\gamma$ 取值越小。小流域土地利用强度系数表示可开发 土地面积率, 与小流域不透水表面比例有关)。 $\gamma$ 可根据小流 域土地利用的水环境阈值效应来确定, 与小流域的自然地理 形态和水文多样性等密切相关, 也与建设形式、建设用地类 型及雨水管理措施有关。其中, 建设用地增长量如何分解到 各个流域, 取决于城市规划区与小流域单元的四种空间拓扑 关系（图 3)：小流域单元包含完整城市规划区（图 3a, 这 种空间拓扑关系在小城市用地规划中比较常见), 建设用地 增长量产生的水环境效应将完全作用于一个完整的小流域单 元, 城市规划区建设用地增长量等于小流域建设用地增长量; 小流域包含部分规划区（图 3b), 需将部分建设用地分解到 该小流域单元；对于整个规划区包含多个完整小流域或多个 小流域的局部（图 3c, 图 3d, 这种空间关系在大都市区中比 较常见), 依据规模效应和功能约束原理, 需将全部建设用 地增长量分解到多个小流域单元。

策略二 : 类型引导策略, 确定 “开发什么”。依据土地利 用的类型效应原理, 引导建设用地类型和水环境敏感区的生态 服务功能, 提出与水环境功能和水质目标相容的土地利用原则。 采用基于水环境容量的管理策略, 才能有效改善城市河流的水 环境状态。为了满足水环境功能和水体水质目标, 基于小流域 污染物总量控制目标和社区居民对水环境的心理需求, 结合次 小流域合理划定生态断面分区, 针对各个分区确定基本用地类 型及水环境绩效标准 (如不透水表面率等控制标准), 引导布 置与河流水环境主导功能相适应的土地利用类型。

策略三: 形态布局策略, 确定 “在何处开发”。确定小流 域水环境敏感区, 如上游水源涵养区、侵蚀控制区、地下水 
补给区、洪泛区、库塘湿地区、水质保持区 (易沉积或易受 污染的上游或周边影响区) 等, 以及体现地方感和具有美学 价值的水域空间, 这几类空间构成了水环境安全的保护用地。 将次小流域划分为高地区、低地汇水区和水输导区等三类水 文区, 水输导区和低地汇水区不宜设置永久性建设用地, 低 地汇水区适宜游唵开放空间而不宜集中开发, 将建设用地导 向小流域高地区域; 通过水输导区和低地汇水区形成的线性 空间连接水环境敏感区, 保护及恢复现存自然特征。依据土 地利用的形态效应原理, 强调支持自然水文过程的非建设用 地紧凑布局结构, 形成相对聚集和形态复杂的非建设用地布 局结构, 构建建设用地与非建设用地空间的有机耦合关系 ${ }^{[29]}$ 。 控制负向水环境效应较大的关键用地选址（如垃圾处理场 等), 组织安排建设用地紧凑布局形态, 降低建设用地的负 向水环境效应。

\section{4 水环境导向下的城市小流域生态断面分区模式}

人类活动和自然环境之间的某种空间秩序, 形成了土地 利用与水环境的内在关联性。明确用地布局的水环境效应及 水环境的空间约束, 构建城市小流域土地利用生态化模式, 可为保障和改善城市河流水环境质量提供空间框架 ${ }^{[5,17,29]}$ 。 城市小流域约束是指其城市开发建设活动受到水环境质量标 准的影响程度。水环境质量标准取决于小流域生态特征、水 环境现状条件和水质目标、水域环境主导功能、水域地方感 和视觉美学特征等因素。约束强度越大的小流域, 对城市小
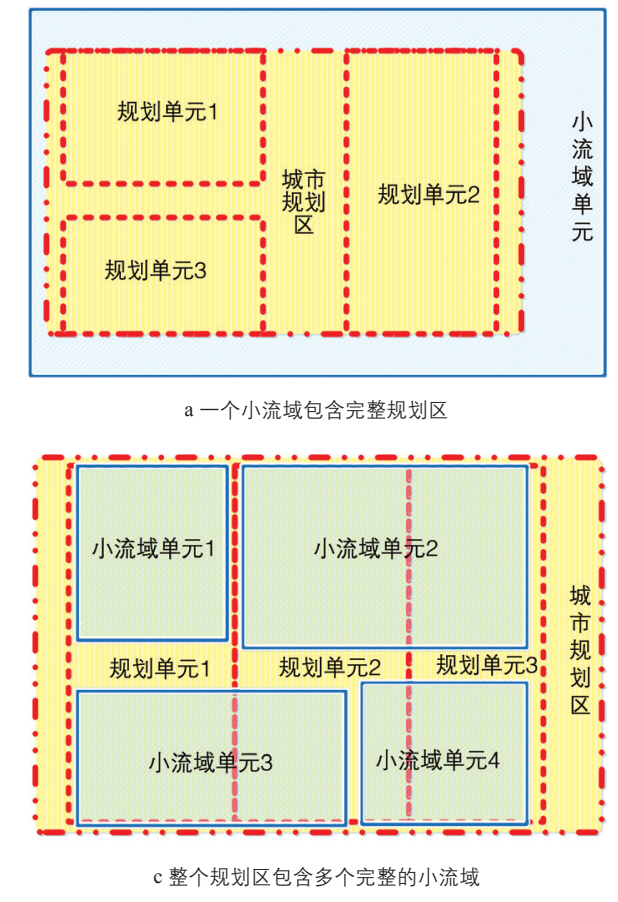

图 3 小流域单元与城市规划区的空间拓扑关系
流域开发控制和排放标准越为严格。为了侧重讨论水环境导 向下的空间规划与控制准则, 本文暂时不讨论影响规划的其 他自然和社会经济因素。由于城市小流域水系空间结构非常 多样, 笔者以树状水系空间为典型特征的城市小流域为例, 针对强约束、中等约束、弱约束等三种不同开发约束条件的 城市小流域, 基于前述的规模控制、类型引导和形态布局等 规划策略, 采用内含了生态伦理价值和水环境目标的断面梯 度分析法, 提出从河源到河口纵向梯度的城市小流域开发断 面概念模式, 试图探索一种基于断面分区的、适应水环境功 能的城市小流域开发形态控制准则 ${ }^{[32]}$ 。

\section{1 城市小流域生态断面分区的确定方法}

基于次小流域特征划分出五类典型生态分区 (ecozones): 环境敏感区、景观感知区、一般城市区、城市中心区、 工业型社区。其中, 环境敏感区有两类 : 保护人类免受自然 灾害影响的区域和保护自然环境免受人类影响的区域, 主要 包括洪水灾害区、降水滑坡区、泥石流地区, 以及上游水源 涵养区、地下水补给区、库塘湿地区、水质保持区、侵蚀控 制区、水生动植物栖息地等, 这类空间为禁止开发或严格限 制开发区。景观感知区是指体现地方感和具有视觉美学价值 的水域空间，包括休闲游䕀区和河口景观区, 涉及观景点和 景物, 包括洁净的溪流、瀑布、湍流、独特水岸林地景观、 桥梁、水岸构筑物、河口湿地景观和其他集体记忆场所等自 然和人工景观空间。这类空间要向公共开放, 需要设置户外
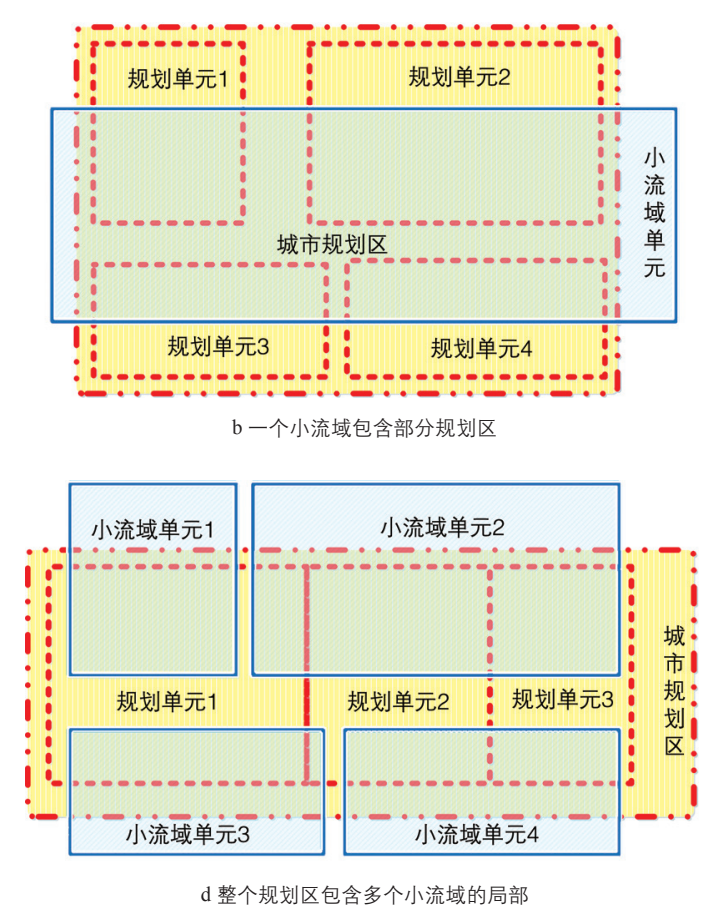
休闲地，如露营地、儿童游乐场、音乐广场等人类集中使用 的空间, 允许低密度与娱乐相关的行为活动, 需铺设良好的 基础设施以加强可达性。一般城市区包括低密度居住型社区 和中密度混合社区，城市中心区包括高密度商业型社区、中 央商务型社区。由于小流域水环境质量标准和城市社会与经 济空间分异特征，上述五类生态断面分区在城市小流域的分 布应该存在显著差异。另外，上述几类典型生态断面分区的 规划控制要素涉及人工环境要素和自然环境要素, 其中人工 环境要素包括土地用途、街道肌理、建筑密度、建筑形态、 开放空间、后退距离、路网密度、步行系统、人工湿地、生 物滞留池、雨水花园、绿色屋面等, 自然环境要素包括水源 涵养林、库塘湿地、侵蚀控制区、河岸生态缓冲带、洪泛区、 野生动物栖息地等, 各类控制要素要以合适的方式与断面分 区联系在一起（表 6)。

\section{2 强约束小流域生态断面分区概念模式}

强约束城市小流域是指水量充足稳定、III类水质目标、 以自然保存和生态保护为主导功能的小流域。这类小流域多 数分布在大都市边缘区, 或分布在新城开发区, 现状林地覆 盖率较高, 小流域生态系统结构完整。为了确保这类小流域 的水域功能正常发挥，基于规模效应阈值原理，小流域的不 透水面积率应控制在 $10 \%$ 以内（建设用地比例控制在 $15 \%$ 左右）。该类小流域强调现状维护和以保护为主的土地利用 模式, 应禁止布置工业用地, 可以布置适量的居住用地以及 少量配套的公共设施用地, 严格限制城市交通设施用地。适 度的小流域开发建设活动主要集中在中下游区域, 从上游河
源至下游河口, 可以基于次小流域将强约束小流域空间分为 环境敏感区、休闲游咊区、低密度居住型社区、河口景观区 等四类生态断面分区 (图 4)。其中, 河源的环境敏感区应 严格限制城市主干道穿越, 原则上禁止任何与生态保护无关 的开发活动, 强化水源涵养和自然保育功能。休闲游憩区和 河口景观区应设置连接滨水区的步行网络体系, 以郊野森林 公园或生态保护等功能为主, 具有一定的自然净化功能, 可 融人少量游憩和科普类配套用地。小流域中下游可以适度布 置中低密度社区, 加强建设用地和非建设用地的紧凑集中布 局形态, 加强滨水空间廊道宽度控制, 增加滨河生态廊道的 联通度。建设用地布置在高地缓坡区域, 尽量远离水域空间, 采用低影响开发模式, 增强水环境自净能力。

\section{3 中等约束小流域生态断面分区概念模式}

中等约束的城市小流域是指水量充足稳定、III或 IV 类水 质目标、以景观娱乐为主导功能的小流域。这类小流域多数 分布在大都市开发新区, 现状林地覆盖率较高, 存在较完整

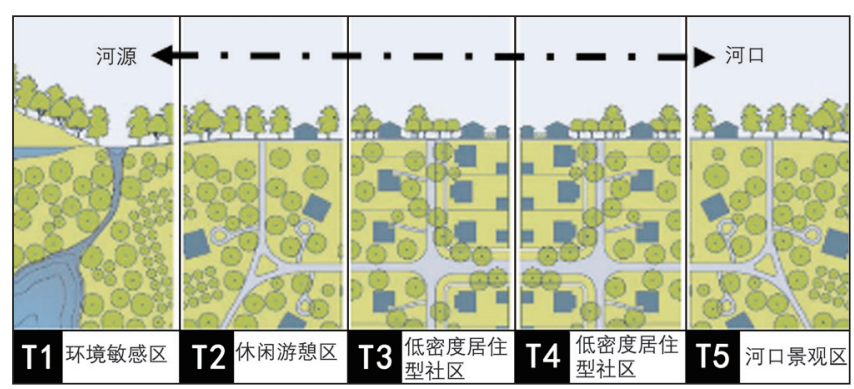

图 4 强约束小流域生态断面分区概念模式

表 6 城市小流域生态断面分区的规划控制要素

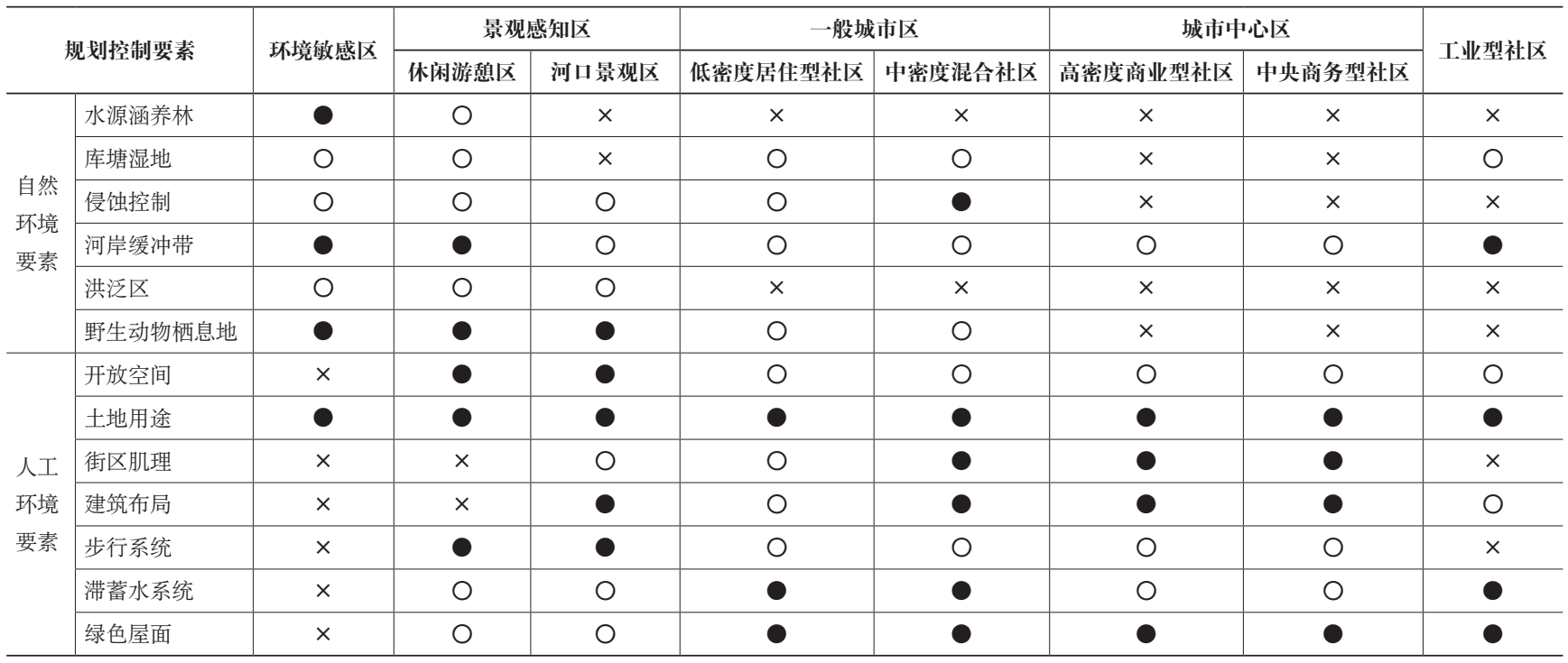

注：○基本控制要素，○引导要素， $\times$ 非控制要素。 
的流域生态系统结构, 但需承载一定强度的开发建设活动。 针对这类小流域的水域功能, 基于规模效应阈值原理, 小流 域的不透水面积率应控制在 10\% 20\% 左右（建设用地比例 控制在 $15 \%$ 35\% 左右)。中等约束小流域可以适度布置居住 用地, 应限制工业用地和商业用地的大规模布局, 减少交通 类用地的水环境影响, 强调采用生态化策略就地平衡开发的 冲击。从上游河源至下游河口, 基于次小流域将中等约束小 流域空间分为休闲游唕区、低密度居住型社区、中密度混合 社区、高密度混合社区、河口景观区等五类生态断面分区（图 5)。其中, 上游水源涵养是下游水量与水质的基础, 河源的 休闲游㮩区以郊野公园和生态游蒩等功能为主, 引导该分区 的水源涵养功能, 维护自然的径流通道和构建连续的步行体 系, 可布置少量的游惒类设施用地。中高密度混合社区宜布 置在该类小流域的中下游区域, 加强建设用地和非建设用地 的紧凑布局形态, 增强水环境自净能力, 强化水系及重要径 流的连通性; 构建社区开放空间并与上游游敀区和下游河口 景观区的连接; 河口景观区可以布局低密度居住型社区以及 少量公共服务设施, 维持或重建连接（下游）更高一级河流 的河岸缓冲区, 减缓该类小流域开发对更高一级河流水环境 的影响。

\section{4 弱约束小流域生态断面分区概念模式}

弱约束小流域是指水质目标为 IV 或 V 类, 以景观娱乐、 泄洪功能为主导功能的小流域。这类小流域多数分布在大都 市中心区, 现状林地覆盖率较低, 小流域生态系统结构不完 整。为了确保这类小流域的最低水域功能正常发挥 (避免黑 臭等水环境恶化现象), 基于规模效应阈值原理, 小流域不 透水面积率应控制在 20\% 30\% 左右（建设用地比例控制在 $40 \% \sim 60 \%$ 左右)。该类水域功能的小流域空间可以承载较高 强度的开发建设活动。为了减少该类小流域对下级河流水环 境的影响, 应采用低影响开发模式减少工业、交通和农业用 地的地表径流污染。

以景观娱乐为主导功能的小流域, 可以承载城市中心区 的高强度开发容量, 允许居住用地、城市商业和交通设施用

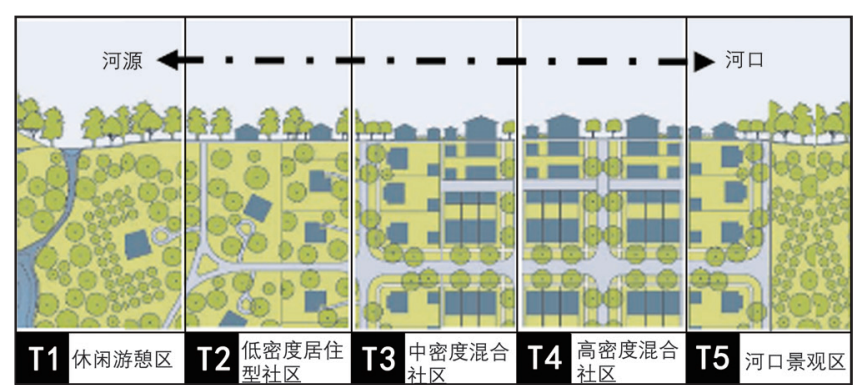

图 5 中等约束小流域生态断面分区概念模式
地的规模化集中布置, 保留现状或布置适度规模的农业用地, 但需要关注水量的维持。从上游河源至下游河口, 基于次小 流域将弱约束小流域空间分为休闲游憩区、低密度居住型社 区、高密度混合社区、中央商务型社区、中密度混合社区等 五类生态断面分区 (图 6)。对以排水泄洪为主导功能的小 流域, 可以在中下游允许工业用地的集中布置, 在河口地带 布置与邻近工业区相关的生产服务业用地。可以将该小流域 空间分为低密度居住型社区、中密度混合社区、工业型社区、 生产服务区等四类生态断面分区（图 7), 工业用地的集中紧 凑, 有利于工业废水集中高效处理。另外, 应采用低影响开 发模式减少工业区和生产服务业设施的降雨径流对（下游） 更高一级河流的影响。

\section{5 结语}

通过解析土地利用与城市小流域水环境的相互作用机 制, 本文初步探讨了提升水环境绩效的关键规划变量, 提出 了“增长需求 $\rightarrow$ 服务供应 $\rightarrow$ 反馈调节” 的小流域生态实践路 径, 是生态实践研究成果在城市小流域水环境管理层面的具 体体现; 从城市小流域的土地利用规模控制、类型引导和形 态布局三个方面提出了生态化策略; 采用内含生态伦理价值 和水环境目标的断面梯度分析法, 提出了从河源到河口纵向 梯度的城市小流域开发断面概念模式。本文主要观点和结论 归纳如下。

首先, 缺乏提升水环境绩效的土地利用和空间规划框架, 是造成城市水环境治理后反复恶化的主要原因。完全依赖于

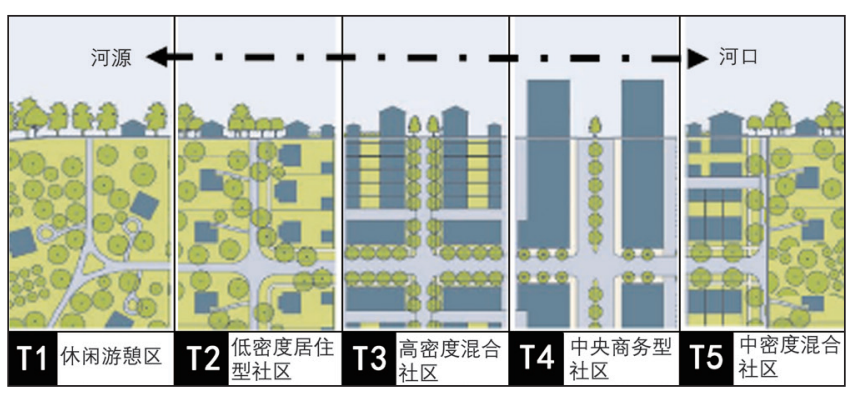

图 6 弱约束小流域生态断面分区概念模式 (一)

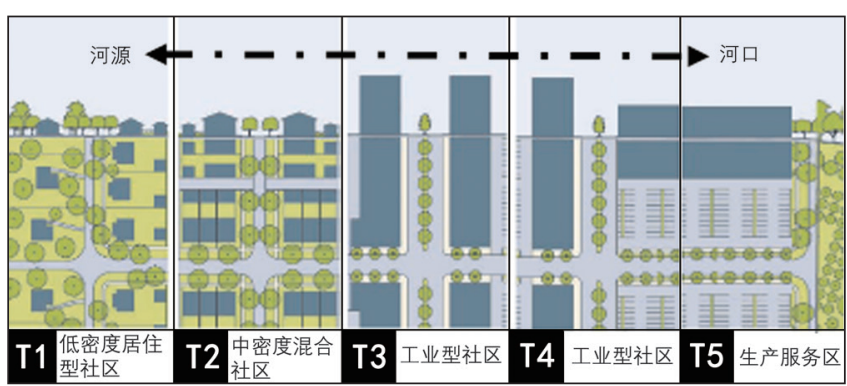

图 7 弱约束小流域生态断面分区概念模式 (二) 
工程技术的水环境治理方式，无法从根本上解决城市水环境 问题。将水环境保护目标整合进城市土地利用规划中, 应将 土地利用规划视为水环境管理的有效工具, 可为城市水环境 管理提供重要的空间政策框架。

其次，城市小流域土地利用与水环境质量的相互关系具 有一定的普遍性, 但又存在较大的地方性特点。由于地形、 地貌、水文地质条件等自然因素都将对城市水环境产生影响, 加之城市小流域生态系统的复杂性、空间尺度的差异性、土 地利用和河流水文过程的动态性, 城市小流域土地利用和水 环境质量的相互关系存在一定的区域性和不确定性。不同地 方水环境特征和社会需求都有差异, 因此在理解普遍性的基 础上还需要研究城市河流水环境的地方性特征。

第三，城市小流域生态断面模式表现了人与自然的空间 梯度关系, 是一种空间要素沿河源至河口的分配方法, 可以形 成应对生态环境问题的一种规划工具。研究提出了理想化的城 市小流域开发断面概念模式, 具体应用时需要根据本地综合环 境特征进行校准。制定城市土地利用规划时还需整合城市各个 小流域的土地利用布局结构, 综合考虑地形、风向、地质、文化、 产业、交通等影响土地利用模式的自然因素和社会经济因素, 如此才能构建城市土地利用的生态化空间结构。

最后, 也是本研究的延伸思考, 涉及资源环境管理的相 关问题。一方面，应将土地利用与空间规划作为整合相关资 源环境保护的政策平台, 确立资源环境保护在空间规划体系 的核心作用; 另一方面, 理解土地利用空间结构与环境演变 的相互关系, 提出空间规划的创新技术和方法, 将量化的资 源和环境保护目标转为空间策略和规划行动, 可以从根本上 提升区域环境的可持续能力。 UP

注: 文中图 4一图 7 由作者在参考文献 [32] 基础上改绘, 其余图片均为作者绘制。

\section{参考文献}

[1] ALI M, KHAN S J. Simulation of the impacts of land-use change on surface runoff of Lai Nullah Basin in Islamabad, Pakistan[J]. Landscape and Urban Planning, 2011, 102(4): 271-279.

[2] 徐光来, 许有鹏, 徐宏亮. 城市化水文效应研究进展 [J]. 自然资源学报, 2010, 25(12): 2171-2177.

[3] 颜文涛, 韩易, 何强.城市径流污染特征分析 [J]. 土木建筑与环境工程, 2011, 33(3): 136-142.

[4] 颜文涛, 周勤, 叶林. 城市土地使用规划与水环境效应: 研究综述 [J]. 重庆师范大学学报 (自然科学版), 2014, 29(3): 35-41.

[5] 颜文涛, 萧敬豪, 胡海, 等。城市空间结构的环境绩效: 进展与思考 [J]. 城市规划学刊, 2012(5): 50-59.

[6] 颜文涛, 萧敬豪. 城乡规划法规与环境绩效——环境绩效视角下城乡 规划法规体系的若干思考 [J]. 城市规划, 2015(11): 39-47.

[7] LEE S W, HWANG S J, LEE S B, et al. Landscape ecological approach to the relationships of land use patterns in watersheds to water quality characteristics[]]. Landscape and Urban Planning, 2009, 92: 80-89.

[8] 张殷俊, 陈爽, 相景昌.河流近域土地利用格局与水质相关性分析以巢湖流域为例 [J]. 长江流域资源与环境, 2011, 20(9): 1054-1060.

[9] ALBERTI M, BOOTH D, HILL K, et al. The impact of urban patterns on aquatic ecosystems: an empirical analysis in Puget lowland sub-basins[J]. Landscape and Urban Planning, 2007, 80: 345-361.

[10] 刘丽娟, 李小玉, 何兴元. 流域尺度上的景观格局与河流水质关系研 究进展 [J]. 生态学报, 2011, 31(19): 5460-5465.

[11] 杨莎莎, 汤萃文, 刘丽娟, 等.流域尺度上河流水质与上地利用的关系 []]. 应用生态学报, 2013, 24(7): 1953-1961.

[12] ARNOLD C L, GIBBONS C J. Impervious surface coverage: the emergence of a key environmental indicator[J]. Journal of the American Planning Association, 1996, 62(2): 243-258.

[13] BRUN S E, BAND L E. Simulating runoff behavior in an urbanizing watershed[J]. Computers, Environment and Urban Systems, 2000, 24(1): $5-22$

[14] HOLLIS G E. The effect of urbanization on floods of different recurrence interval[J]. Water Resources Research, 1975, 11(3): 431-435.

[15] LEOPOLD L B. Hydrology for urban land planning: a guidebook on the hydrologic effects of urban land use[C]. US Geological Survey Circular 554, 1968.

[16] 刘珍环, 曾祥坤。深圳市不透水表面扩展对径流量的影响 [J]. 水资源保 护, 2013, 29(3): 44-50.

[17] 陈雯. 流域土地利用分区空间管制研究与初步实践——太湖流域为 例 [J]. 湖泊科学, 2012, 24(1): 1-8.

[18] 岳隽, 王仰麟, 李贵才, 等. 基于水环境保护的流域景观格局优化理念 初探 [J]. 地理科学进展, 2007, 26(3), 38-45.

[19] KLEIN R D. Urbanization and stream quality impairment[J]. Water Resources Bulletin, 1979, 15(4): 948-963.

[20] TODD D A, BENIENT P B, HAASBEEK J F, et al. Impact of land use and NPS loads on lake quality[J]. Journal of Environmental Engineering, 1989, $115(3): 633-649$

[21] BOOTH D. Urbanization and the natural drainage system: impacts, solutions and prognoses[J]. Northwest Environmental Journal, 1991, 7(1): 93-118.

[22] BHADURI B, HARBOR J, ENGEL B, et al. Assessing watershed-scale, long-term hydrologic impacts of land-use change using a GIS-NPS model[J]. Environmental Management, 2000, 26(6): 643-658.

[23] Center for Watershed Protection. Impacts of impervious cover on aquatic systems $[R]$. Watershed Protection Research Monograph No. 1. Ellicott City, Maryland, 2003.

[24] 岳隽, 王仰麟, 李正国, 等.河流水质时空变化及其受土地利用影响的 研究——深圳市主要河流为例 [J]. 水科学进展, 2006, 17(3): 359-364.

[25] 廖义善, 卓慕宁, 李定强, 等. 基于 “径流一地类” 参数的非点源氮磷 负荷估算方法 []]. 环境科学学报, 2014, 34(8): 2126-2132.

[26] 傅伯杰, 张立伟. 土地利用变化与生态系统服务: 概念、方法与进展 [J]. 地理科学进展, 2014, 33(4): 441-446.

[27] 邹锦, 颜文涛, 曹静娜, 等。绿色基础设施实施的规划学途径—基于 与传统规划技术体系融合的方法 [J]. 中国园林, 2014(9): 92-95.

[28] XIANG W N. Ecophronesis: the ecological practical wisdom for and from ecological practice[J]. Landscape and Urban Planning, 2016(155): 53-60.

[29] 颜文涛, 王正, 韩贵锋, 等. 低碳生态城规划指标及实施途径 [J]. 城市 规划学刊, 2011(3): 39-50.

[30] 颜文涛, 王云才, 象伟宁. 城市雨洪管理实践需要生态实践智慧的引 导 [J]. 生态学报, 2016, 36(16): 4926-4928.

[31] 颜文涛, 象伟宁, 袁琳, 探索传统人类聚居的生态智慧——以世界文 化遗产区都江塸灌区为例 [J]. 国际城市规划, 2017(4): 1-9.

[32] DUANY A, TALEN E. Transect planning[J]. Journal of the American Planning Association, 2002, 68(3): 245-266. 